\title{
Food supply (Orthoptera, Mantodea, Rodentia and Eulipotyphla) and food preferences of the red-footed falcon (Falco vespertinus) in Slovakia
}

\author{
Potravná ponuka (Orthoptera, Mantodea, Rodentia a Eulipotyphla) a potravné preferencie \\ sokola kobcovitého (Falco vespertinus) na Slovensku
}

\author{
Anton KRIŠTín, Filip TULIS, Peter KLIMANT, Kristián BACSA \& Michal AMBROS
}

\begin{abstract}
Food supply in the nesting territories of species has a key role to the species diet composition and their breeding success. Red-footed falcon (Falco vespertinus) preys predominantly on larger insect species with a supplementary portion of smaller vertebrates. In the breeding periods 2014 and 2016 their food supply, focusing on Orthoptera, Mantodea, Rodentia and Eulipotyphla, was analysed at five historical nesting sites of the species in Slovakia. Preference for these prey groups in the diet was also studied at the last active nesting site in this country. Overall we recorded 45 Orthoptera species (of which 23 species are known as the food of the red-footed falcon), one species of Mantodea, 10 species of Rodentia (of which 2 species are known as the food of the red-footed falcon) and 5 species of the Eulipotyphla order in the food supply. With regard to the availability of the falcons' preferred food, in both years the most suitable was the Tvrdošovce site, which continuously showed the greatest range and abundance of particular species. In the interannual comparison the insects showed lower variability in abundance than the small mammals. In 2014 the growth of the common vole (Microtus arvalis) population culminated and with the exception of a single site (Bodza) a slump in abundance was recorded in 2016. In comparing the diet composition with the food supply at the last Slovak breeding site Rusovce (Special Protection Area Syslovské polia), we recorded significant preference for grasshopper Caliptamus italicus (in 2014), common vole (in 2016) and cricket Tettigonia viridissima (in both years) in the falcons' diet. They did not prey on the Apodemus sylvaticus species belonging among the abundant small mammal species in that locality. Conservation measures in the agricultural landscape are discussed in relation to homogeneous red-footed falcon breeding territories.
\end{abstract}

\begin{abstract}
Abstrakt: Potravná ponuka v hniezdnych teritóriách druhov hrá klúčovú úlohu pre zloženie potravy druhov a ich hniezdny úspech. Sokol kobcovitý (Falco vespertinus) loví prevažne väčšie druhy hmyzu, dopíňané menšími stavovcami. V hniezdnom období rokov 2014 a 2016 bola na piatich historických hniezdiskách druhu na Slovensku sledovaná jeho potravná ponuka so zameraním na Orthoptera, Mantodea, Rodentia a Eulipotyphla. Na poslednom aktívnom hniezdisku sa študovalo aj zastúpenie týchto skupín v potrave. Celkovo sme zaznamenali 45 druhov Orthoptera (z toho 23 druhov je známych ako potrava sokola kobcovitého), jeden druh Mantodea, 10 druhov Rodentia (z toho 2 druhy sú známe ako potrava sokola kobcovitého) a 5 druhov radu Eulipotyphla. Z hl'adiska potravnej ponuky bola v oboch rokoch najvhodnejšia lokalita Tvrdošovce, ktorá kontinuálne vykazovala najvyššie druhové bohatstvo a abundanciu jednotlivých druhov. V medziročnom porovnaní hmyz vykazoval menšiu variabilitu početnosti ako drobné cicavce. V roku 2014 totiž vrcholila gradácia populácie hraboša pol’ného (Microtus arvalis), ktorá s výnimkou jednej lokality (Bodza) zaznamenala v roku 2016 prepad početnosti. Pri porovnaní zloženia potravy s potravnou ponukou na poslednej hniezdnej lokalite na Slovensku - Rusovce (Chránené vtáčie územie Sysl'ovské polia) - sme zaznamenali preukaznú preferenciu lovu druhov Caliptamus italicus (v roku 2014), Microtus arvalis (v roku 2016) a Tettigonia viridissima (počas oboch rokov). Sokol nepreferoval druh Apodemus sylvaticus, ktorý patril k početným druhom drobných cicavcov na lokalite. $\mathrm{V}$ závere diskutujeme o možných opatreniach s ciel’om ochrany sokola kobcovitého v homogénnych hniezdnych teritóriách polnohospodárskej krajiny.
\end{abstract}

Key words: foraging ecology, birds of prey, Falco vespertinus, food availability, conservation measures

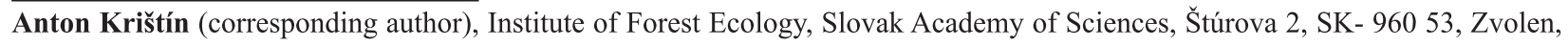
Slovakia. E-mail: kristin@savzv.sk.

Filip Tulis, Kristián Bacsa, Department of Ecology and Environmental Sciences, Faculty of Natural Sciences, Constantine the Philosopher University in Nitra, Tr. A. Hlinku 1, 949 74, SK-949 01 Nitra, Slovakia. E-mail: ftulis@ukf.sk.

Peter Klimant, Institute of Virology, Biomedical Research Center, Slovak Academy of Sciences, Dúbravská cesta 9, 84505 Bratislava, Slovakia. E-mail: peter.klimant@savba.sk.

Michal Ambros, State Nature Conservancy of the Slovak Republic, Protected Landscape Area Ponitrie, Samova 3, 94901 Nitra, Slovakia. E-mail: michal.ambros@sopsr.sk. 
Acknowledgment: This research was carried out within the project LIFE 11/NAT/HU/000926 Conservation of Red-footed Falcon in the Carpathian Basin.

\section{Introduction}

The primary factor determining the individual diet and breeding success of raptors is evidently the range of available prey in the predators' territory (Martin 1987, Ontiveros \& Pleguezuelos 2000, Hoi et al. 2004). In fact, the prey animals must be not only present, but constantly available and accessible (Holmes \& Schultz 1979, Mikola 1985). Food availability represents a fundamental factor in the raptors' diet composition, and fluctuations in availability influence not only their functional or numerical responses (Andersson \& Erlinge 1977, Korpimäki \& Norrdahl 1991), but also their spatial activity (Village 1982), intra- and interspecific competition (Morosinotto et al. 2017) and have a significant impact on their breeding success, individual fitness and population dynamics (Korpimäki 1984, Korpimäki \& Wiehn 1998, Ontiveros \& Pleguezuelos 2000).

The red-footed falcon (Falco vespertinus), as a mostly insectivorous and migratory raptor species, can be found in Central Europe from April until October (Danko 2008). Its diet is composed mainly of flying insect species (mostly Orthoptera, Coleoptera and Odonata), and to a lesser extent of vertebrates (Mammalia, Amphibia) (Balát \& Bauer 1955, Keve \& Szijj 1957, Purger 1998, Tulis et al. 2017). This raptor is highly opportunistic, making use of local abundances and seasonal variations in prey, with orthopterans as its principal food (Cramp 1980, Szövényi 2015). However, short-term changes in the diet composition may occur even due to the impact of meteorological factors (Horváth 1963, Haraszthy et al. 1994).

In the past, this species occupied several sites in Slovakia (Gúgh et al. 2015), but since the 1970s its population size has decreased sharply (Slobodník et al. 2014). Nowadays, the last breeding colony is situated in the Special Protection Area (SPA) Sysl'ovské polia in south-western Slovakia. To date the reason for the falcons' disappearance from their former breeding sites is unknown, and so we have tried to show the effect of location on the food supply for this falcon species.

The availability of Orthoptera as food for the redfooted falcon was studied in the area of Vásárhelyi Plain in Hungary using an extensive collection of material (Szövényi, 2015). This study also focused on de- fining the red-footed falcon friendly habitats for potential habitat management. Other data on the food supply and its effect on the species diet are insufficient.

Based on recent knowledge we have analysed: i) the food supply (Orthoptera, Mantodea, Rodentia and Eulipotyphla) and its variability at five historically known breeding sites in south-western Slovakia; and ii) how the food supply is reflected in the species diet composition at the last nesting site of the species in Slovakia.

\section{Methods}

S t u d y a r e a

We studied the food supply in five historical breeding localities of red-footed falcon (RFF) and one current breeding site in the southern part of western Slovakia. Study sites are delimited as plots of circular shape with a diameter of $3 \mathrm{~km}$ and an overall plot area of 2827 ha. The plots are situated in an agricultural landscape, and form parts of protected bird areas (Fig. 1) as follows:

1. Rusovce, SPA Sysl'ovské polia, GPS of the centre $48^{\circ} 01^{\prime} \mathrm{N}, 17^{\circ} 07^{\prime} \mathrm{E} ; 135 \mathrm{~m}$ a.s.l..; the current nesting site is characterized by intensively cultivated fields, several windbreaks and field spinneys. Almost $44 \%$ of the study plot is located in Austria, characteristic for its mosaic structure of narrow fields.

2. Lehnice, SPA Lehnice, $48^{\circ} 04^{\prime} \mathrm{N}, 17^{\circ} 27^{\prime} \mathrm{E} ; 119 \mathrm{~m}$ a.s.1.; this former nesting site from before 2004 is situated to the north of the village of Lehnice, within intensively cultivated fields, windbreaks and field spinneys.

3. Zeleneč, SPA Úl'anská mokrad', $48^{\circ} 17^{\prime} \mathrm{N}, 17^{\circ} 35^{\prime}$ $\mathrm{E} ; 133 \mathrm{~m}$ a.s.l.; this former nesting site from before 2001 is characterized mainly by intensively cultivated field biotopes, several windbreaks and spinneys, and strips alongside the motorway in the vicinity of the Zeleneč services area.

4. Bodza, SPA Ostrovné lúky, 47 $51^{\prime} \mathrm{N}, 17^{\circ} 53^{\prime} \mathrm{E}$, $110 \mathrm{~m}$ a.s.l.; this former nesting site from before 1993 is situated SE from the Bodzianske Lúky village and it is typical for its intensively cultivated fields, old riverbeds with accompanying tree vegetation, field spinneys and the Rakytie dispersed settlement.

5. Tvrdošovce, SPA Dolné Považie, $48^{\circ} 06^{\prime} \mathrm{N}, 18^{\circ} 01^{\prime}$ $\mathrm{E} ; 110 \mathrm{~m}$ a.s.1.; this former nesting site from before 2010 is the most diversified of all five studied sites and 
study plots represent the main previous foraging territories of the red-footed falcon, characterized mainly by permanent grasslands with various degrees of salinization (salt marshes), vineyards with varied intensity of cultivation, and bright poplar forest with nesting boxes provided for the falcons.

When mapping the availability of Orthoptera and Mantodea, we excluded extensive areas of arable land and monocultures of annual agrarian cultures (corn, maize, oilseed rape) in which the supply of the studied insects is negligible, even though sometimes the flying species pass over them and thus they are accessible to "air-hunting falcons". In contrast, from the viewpoint of occurrence, species richness and Orthoptera abundance, the following are considered attractive: mainly permanent grasslands, edges of field spinneys, windbreaks and avenues of trees, wetland areas with dispersed bush and tree vegetation, and edges of such biotopes, in some cases their mosaic representation, all with higher Orthoptera diversity.
The line elements of vegetation (avenues, windbreaks) were selected for the monitoring of small mammals. At the end of summer, when the agrotechnical interventions in the agricultural landscape culminate, the greenery transects form refuges for small mammals and thus they make it possible to capture a wide species spectrum of small mammals available at the studied sites.

S a mpling Orthoptera and Mantodea a $\mathrm{s}$ food supply

Every site was visited twice a year, first in the early summer period, during the feeding phase of falcons (June 30, July 31 and August 1, 2014; June 29, July 13 and August 1,2016) and second during the fledgling period (August 25 and September 1, 2014; August $24-25,2016)$ in order to sample the widest species spectrum possible, occurring in both seasonal aspects. The material was sampled mostly by sweeping herb and shrub vegetation (cca. 1,000 sweeps per site/visit/hab-

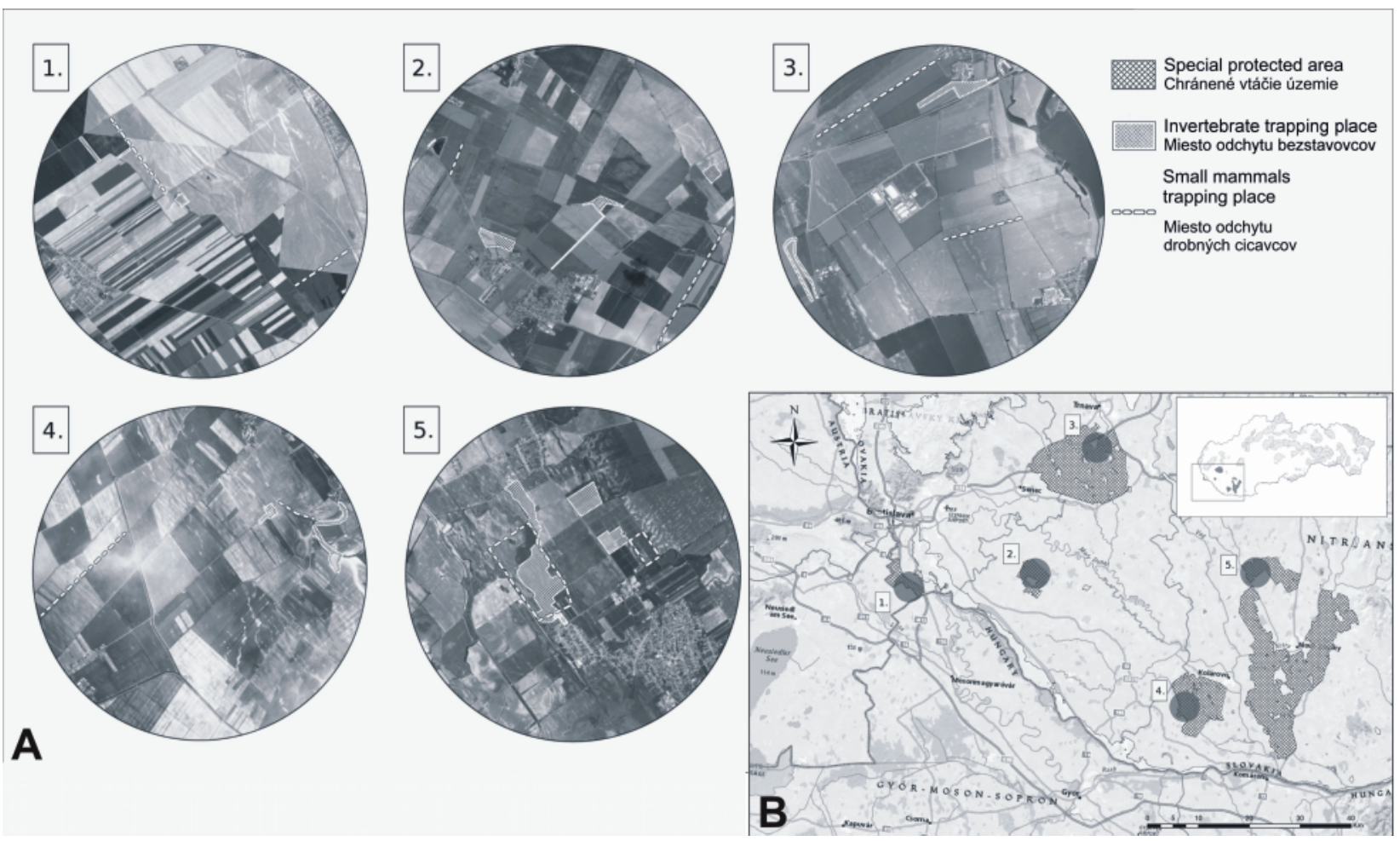

Fig. 1. Five study sites of red-footed falcon food supply (A) and their locations in Slovakia (B). Sites: 1 - Rusovce, 2 - Lehnice, $3-$ Zeleneč, 4 - Bodza, 5 - Tvrdošovce.

Obr. 1. Pät' študovaných lokalít potravnej ponuky sokola kobcovitého (A) a ich lokalizácia na Slovensku (B). Lokality: 1 - Rusovce, 2 - Lehnice, 3 - Zeleneč, 4 - Bodza, 5 - Tvrdošovce. 
itat). This method was supplemented with acoustic identification, beating from the lower parts of trees and shrubs, and individual collection of specimens. We spent at least two hours of collection at each site. Abundance of individual species at the studied sites was expressed using the following classification scale: $1-$ very rare (less than 3 adult specimens), 2 - rare (3-10 specimens), 3 - abundant (11-100 specimens), 4 - very abundant (more than 100 specimens), when the highest semiquantitative value is given (Tab. 1).

Altogether, cca. 8,000 individuals of Orthoptera and Mantodea were identified in 2014 and cca. 6,500 individuals in 2016. The material was identified by means of identification keys (Harz 1969, 1975). The system and nomenclature proceed from the work of Kočárek et al. (2005).

$\mathrm{S}$ a mpling s m a $11 \mathrm{~m}$ a m m a $1 \mathrm{~s}$ a $\mathrm{s}$ f o o d s u p p 1 y

Small mammals were captured in August and September by means of the CMR method (capture - mark - recapture). Live traps (50 per line) were located in a trapping line at $10 \mathrm{~m}$ distance from each other. At each study site, two trapping lines were exposed. In 2014 the traps were exposed for 2 nights $(2 \times 50$ traps $\times 2$ nights), while in 2016 the traps were exposed only for 1 night $(2 \times 50$ traps $\times 1$ night $)$. The captured individuals were identified and marked. Only the data from the first capture of individuals were entered into analyses. The system and nomenclature proceed from the work of Baláž et al. (2013). As the length of the exposition of traps in 2014 differed from the year 2016, the data on capture of small mammals were standardised by correction to 50 trap-nights.

Food supply estimation a t s t u d y s it e s

The study sites were evaluated based on several factors: i) overall number of Orthoptera, Mantodea, Rodentia and Eulipotyphla species; ii) number of species known as the food of red-footed falcons and recorded primarily in the territory of Slovakia in the works of Balát \& Bauer (1955) and Tulis et al. (2017), and also in the diet of other parts of the Pannonian Lowlands (Fülöp \& Szlivka 1988, Haraszthy et al. 1994, Purger 1998, Szövényi 2015); and iii) abundance of individual species. For Orthoptera and Mantodea this was expressed with semiquantitative values (see above), while the locality score was calculated for each site: the sum of semiquantitative values (1-4) in all the studied plots of the locality was divided by the number of studied plots.

Site effect of the species diet composition of Orthoptera, Mantodea and small mammals on the semiquantitative values, separately during both studied years, was evaluated using a general linear model with Poisson distribution.

\section{Di e t prefere nce a n a ly s is}

We calculated the diet preference of red-footed falcons at their active breeding site Sysl'ovské polia during the years 2014 and 2016. Food supply from this site was compared with the diet of red-footed falcons in the same years (Tulis et al. 2017) using the Ivlev-index (Ivlev 1961) using the "selectapref" package (Richardson 2017), where: $P x=(a-b) /(a+b)$, in which "a" is the proportion of caught animals in the given area, " $b$ " is the proportion of the given area in relation to the whole. "Px" is the preference $(-1 \leq \mathrm{Px} \leq 1)$ or avoidance of each prey species $(+1$ is absolute preference, -1 is absolute avoidance). Calculation only using the Ivlev-indexes would not be sufficient for demonstrating whether the preference values of the habitat types are significant or not. Hence we tested significance $(P<0.05)$ using the Bonferroni z-test (Neu et al. 1974).

All statistical analyses were performed using the $\mathrm{R}$ software v. 3.2.5 (R Core Team 2016).

\section{Results}

Orthoptera and M a n t o d e a species as the food supply for Falco vespertinus

Altogether 45 Orthoptera (around $36 \%$ of the orthopterofauna of Slovakia) and one mantid species were found at five sites ( 20 plots) in the former and current nesting territories of the red-footed falcon in south-western Slovakia in 2014 and 2016. Of them there were 22 katydid and cricket species (Ensifera), 23 grasshopper species (Caelifera) and one mantid species (Mantodea). In 2014 there were found altogether 44 Orthoptera species (21 Ensifera and 23 Caelifera species) and in 2016 there were two grasshopper species less, i.e. 42 Orthoptera species (21 Ensifera and 21 Caelifera species) (Tab. 1). Mantids were found in both years.

Comparing the food supply between the two years, there were three species less (Phaneroptera falcata, Tetrix bipunctata and Tetrix undulata) in 2016, but we found one rare bush-cricket Platycleis affinis more in Tvrdošovce. In total we found at least 23 species inter- 
esting as food supply for the studied falcon species and 15 species rare from the viewpoint of zoogeography and faunistics.

Altogether 22-33 species were found at the particular sites in 2014 and slightly more, 23-38 Orthoptera species in 2016 (Fig. 2). Mantids were found at all sites. The species abundance at the particular sites was related to the vegetation diversity, mosaic of microhabitats, and the level of preservation or isolation of the locality.

Orthoptera in the food sup-
p ly of RFF at the Rusove
site

Altogether 23 Orthoptera species were found there (in both 2014 and 2016), mainly in the ecotones of field spinneys and windbreaks. The species considered interesting as food for RFF are mainly Ruspolia nitidula, Platycleis veyseli, Tettigonia viridissima, Gryllus campestris, Calliptamus italicus, Oedipoda caerulescens, Aiolopus thalassinus. Rare species from this site were katydids Phaneroptera nana, $R$. nitidula and macropterous individuals of $P$. veyseli. The most abundant species were tree crickets Oecanthus pellucens and grasshoppers Euchorthippus declivus, Chorthippus apricarius and Chorthippus biguttulus (Tab. 1).

\section{Orthoptera in the food sup- ply of RFF at the Lehnice $\mathrm{s}$ i t e}

We found there 25 and 26 Orthoptera species in both studied years. The species considered most valuable from the viewpoint of food supply for RFF were mainly bush-crickets $R$. nitidula, T. viridissima, species of Metrioptera genus, crickets Gryllotalpa gryllotalpa and $G$. campestris. The most abundant species, similarly to the other sites, were tree cricket $O$. pellucens, grasshoppers E. declivus, C. apricarius, C. biguttulus, though most of the studied plots were strongly ruderalized. The rarer species at this site were $P$. nana, $R$. nitidula, crickets Pteronemobius heydenii, Xya pfaendleri (on the bank of the reservoir $1.5 \mathrm{~km}$ north of the village of Lehnice), Mantis religiosa was also rather abundant there.

Orthoptera in the food su pply of RFF at the $\mathrm{Z}$ e 1 e ne č $\mathrm{s}$ i t e

Altogether 23 and 24 Orthopera species (2014 and 2016) were found there, which is the lowest species number in comparison to the other studied sites, prob-

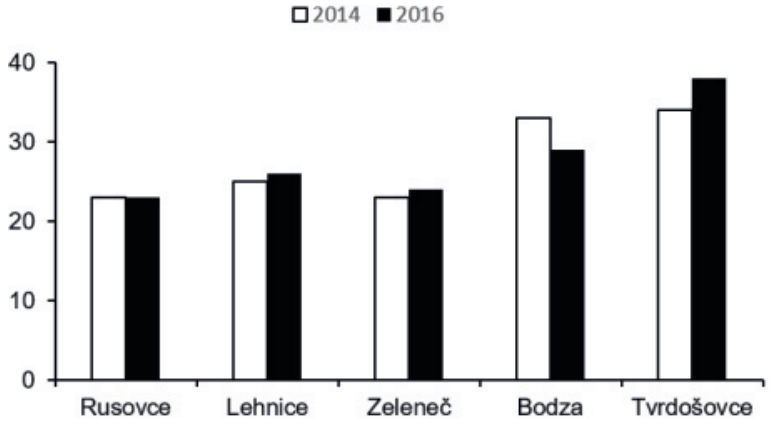

Fig. 2. Number of Orthoptera and Mantodea species at five studied red-footed falcon sites in 2014 and 2016.

Obr. 2. Počet druhov Orthoptera a Mantodea na piatich študovaných lokalitách sokola kobcovitého v r. 2014 a 2016.

ably due to little-preserved biotopes at the studied site, which appears to be the least suitable for the target falcon species nowadays. The species valuable for the food of RFF were $P$. nana, $R$. nitidula, $T$. viridissima, $G$. gryllotalpa, while Platycleis grisea was the species typical for this site. We also found there an allien bush cricket Meconema meridionale, which at that time was only the third species record in Slovakia after Bratislava and Zvolen (Vlk et al. 2012). The most abundant were tree crickets O. pelluscens, grasshoppers $E$. declivus, $C$. apricarius, $C$. biguttulus.

Orthoptera in the food supply of RFF a t the Bodza site Overall, we found 33 and 29 Orthoptera species here (2014 and 2016 respectively). The most valuable food supply for RFF consisted of P. nana, Conocephalus fuscus, Conocephalus dorsalis, $R$. nitidula, T. viridissima, two species of Metrioptera genus, and G. gryllotalpa, $C$. italicus. Several of these species occur there mostly because of the amount of wetland biotopes in the studied plots, several of which belong among the most abundant ones.

Orthoptera in the food supply of RFF a the Trrdošovee s i t e

This site is highly valuable from the viewpoint of the well-preserved state of halophytic vegetation and fauna, also regarding orthopterans. The most species of all the studied sites were found here, 34 in 2014 and 38 in 2016. Bush-crickets $P$. veyseli, $P$. affinis, Decticus ver- 


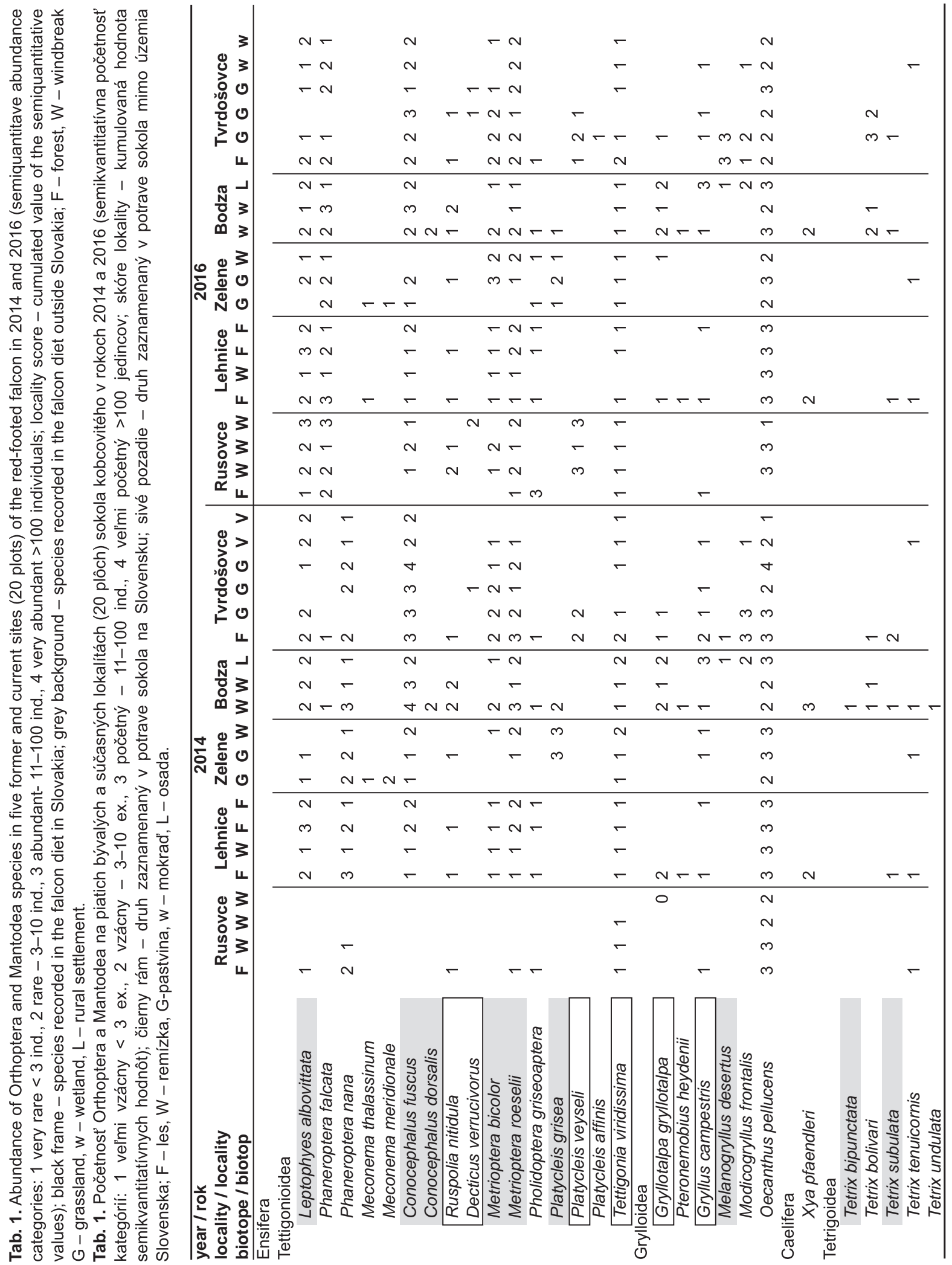


Slovak Raptor Journal 2017, 11: 1-14. DOI: 10.1515/srj-2017-0005.

(C) Raptor Protection of Slovakia (RPS)

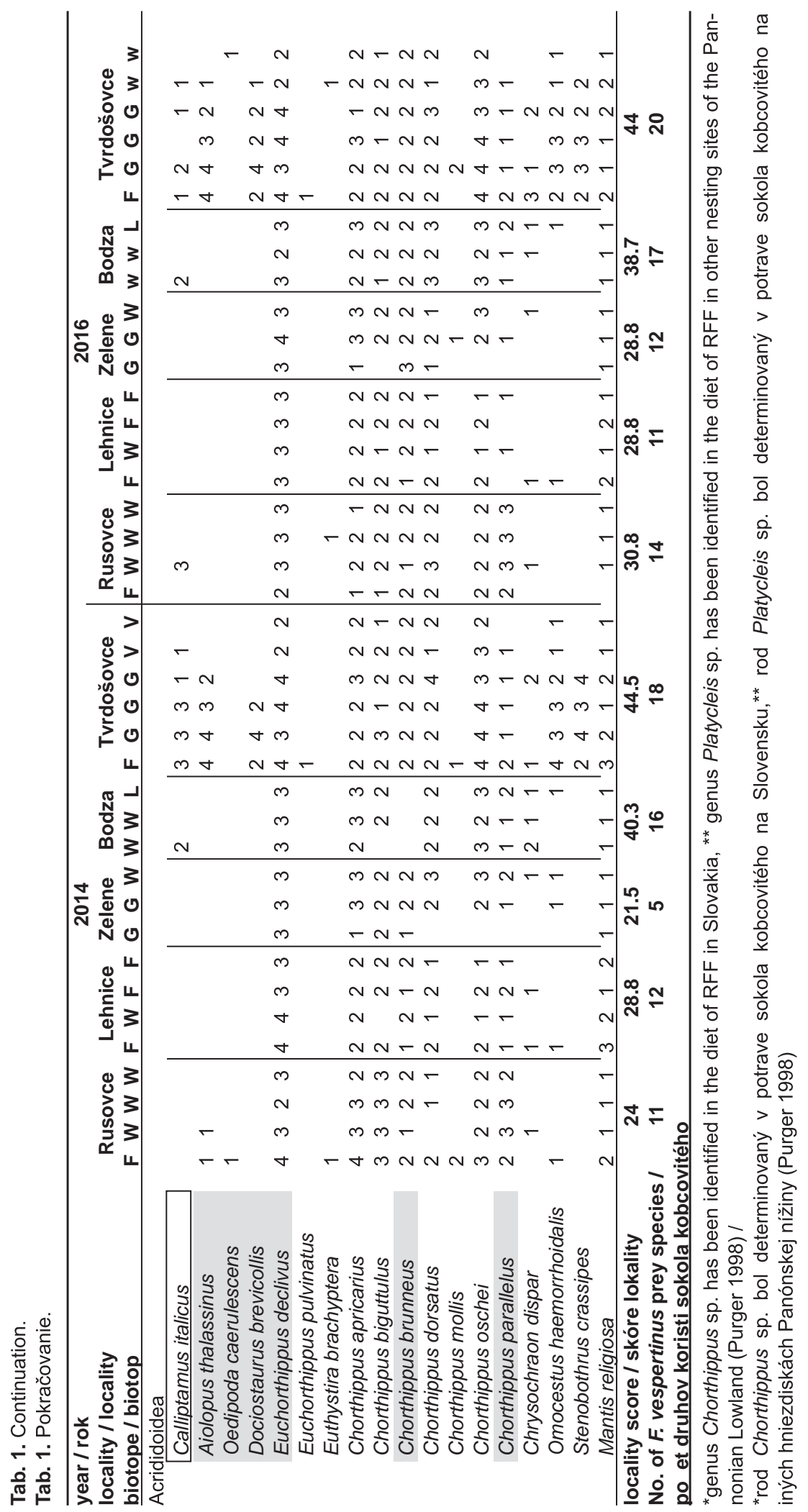




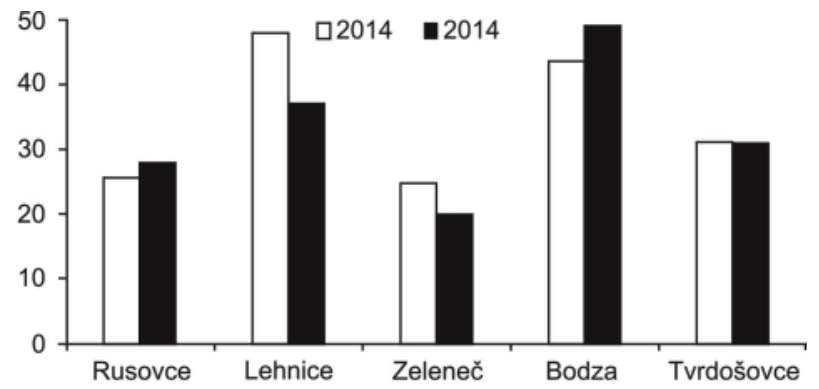

Fig. 3. Number of small mammal species at five studied redfooted falcon sites in 2014 and 2016.

Obr. 3. Počet druhov drobných cicavcov na piatich študovaných lokalitách sokola kobcovitého v r. 2014 a 2016.

rucivorus, crickets Melanogryllus desertus and Modicogryllus frontalis, grasshoppers Aiolopus thalassinus, Dociostaurus brevicollis, and Stenobothrus crassipes may be mentioned as the most valuable orthopteran species. The most abundant species were grasshoppers A. thalassinus, Chorthippus dorsatus and $C$. oschei, thermophilic Ponto-Mediterranean species $E$. declivus and in the salt marshes of the highest quality also the thermophilic grasshoppers $S$. crassipes, which were often one of the most abundant. The most abundant overall there were the katydids and crickets $C$. fuscus species, O. pellucens on tall herbaceous plants and shrubs, and Metrioptera roeselii, grasshoppers Calliptamus italicus and Omocestus haemorrhoidalis on the ruderal vegetation (Tab. 1).

$\mathrm{S} m$ a $11 \mathrm{~m}$ a m m a $1 \mathrm{~s} \quad(\mathrm{R} o \mathrm{de} \mathrm{nt}$ i a and Eulipotyphla) as the food supply for Falcovespertinus

Altogether ten rodent species and five Eulipotyphla species were found as food supply at five sites (10 trapping lines), the former and current RFF nesting territories in 2014 and 2016. In 2014, there were 15 species and 13 in 2016 (Tab. 2). Comparing the years 2014 and 2016 we did not record fluctuations in the abundance of small mammals. Only the abundance of common vole rapidly dropped in 2016 (with the exception of the Bodza site).
S m a 11 mam a $1 \mathrm{~s}$ in the food supply of RFF a $t$ the

$\mathrm{Ru} \mathrm{s}$ o v c e site

Altogether 7 species of small mammals were recorded there in 2014 (Tab. 2). The common vole (66.6\%) and wood mouse (Apodemus sylvaticus) $(9.8 \%)$ were the most abundant species there. Common vole is important in the diet of RFF. In 2016 similarly 7 small mammal species were found there, however by then the most abundant species were bank vole (Clethrionomys glareolus) $(39.3 \%)$ and $M$. arvalis (25\%), while $A$. sylvaticus was represented at $14.3 \%$.

S mall ma m mals i n the foo d supply of RFF a t the Le hnice s i t e

Altogether 7 species of small mammals were recorded here in 2014 (Tab. 2). The yellow-necked mouse (Apodemus flavicollis) (36.5\%), A. sylvaticus $(22.9 \%)$ and common vole $(21.9 \%)$ were the most abundant species. A. sylvaticus and $M$. arvalis are the species which are significant from the viewpoint of the red-footed falcon diet. In 2016 we recorded only three small mammal species there, the most abundant being $A$. flavicollis (54.1\%), C. glareolus $(29.7 \%)$ and A. sylvaticus (16.2\%). In 2016 the common vole was absent there.

S m a $11 \mathrm{mammals}$ i $\mathrm{n}$ the food supply of RFF a t $t$ h e $Z$ e le ne č s it e

Altogether 6 species of small mammals were recorded there in 2014 (Tab. 2). The most abundant was M. arvalis $(59.2 \%)$. M. arvalis and A. sylvaticus $(14.3 \%)$ are species significant from the viewpoint of the diet of RFF. In 2016 we recorded 5 species of small mammals there. The most abundant was A. flavicollis (65\%). In 2016 the common vole was absent there.

S mall mammals in the food supply of RFF a t the Bodza s i t e

Altogether 6 small mammal species were recorded here in 2014 (Tab. 2). The most abundant species were M. arvalis $(65.5 \%)$ and A. sylvaticus (18.4\%). Both of these species are significant prey of the red-footed falcon. In 2016 we recorded 7 species of small mammals there. The most abundant species were $M$. arvalis $(55.1 \%)$ and striped field mouse (Apodemus agrarius) (28.6\%), while $A$. sylvaticus abundance decreased significantly (2\%). 
Tab. 2. Small mammals (Rodentia and Eulipotyphla) in the food supply in five former and current nesting sites of Falco vespertinus (abundances of species are indicated to 50 trap-nights; black frame $=$ species recorded as red-footed falcon (RFF) prey in Slovakia; L1 - $1^{\text {st }}$ line, L2 - $2^{\text {nd }}$ line. Sites: Rus - Rusovce, Leh - Lehnice, Zel - Zeleneč, Bod - Bodza, Tvr - Tvrdošovce.

Tab. 2. Drobné cicavce (Rodentia a Eulipotyphla) v potravnej ponuke na 5 minulých a súčasných hniezdnych lokalitách Falco vespertinus (početnost' druhov je uvádzaná v prepočte na 50 pasconocí; čierny rám - druh zaznamenaný v potrave sokola kobcovitého na Slovensku; L1 - 1. línia, L2 - 2. línia, Lokality: Rus - Rusovce, Leh - Lehnice, Zel - Zeleneč, Bod - Bodza, Tvr Trrdošovce.

\begin{tabular}{|c|c|c|c|c|c|c|c|c|c|c|c|c|c|c|c|c|c|c|c|c|}
\hline \multirow{3}{*}{$\begin{array}{l}\text { year / rok } \\
\text { locality / lokalita } \\
\text { biotope / biotop }\end{array}$} & \multicolumn{10}{|c|}{2014} & \multicolumn{10}{|c|}{2016} \\
\hline & \multicolumn{2}{|c|}{ Rus } & \multicolumn{2}{|c|}{ Leh } & \multicolumn{2}{|c|}{ Zel } & \multicolumn{2}{|c|}{ Bod } & \multicolumn{2}{|c|}{ Tvr } & \multicolumn{2}{|c|}{ Rus } & \multicolumn{2}{|c|}{ Leh } & \multicolumn{2}{|c|}{ Zel } & \multicolumn{2}{|c|}{ Bod } & \multicolumn{2}{|c|}{ Tvr } \\
\hline & L1 & L2 & L1 & L2 & L1 & $\mathbf{L 2}$ & L1 & L2 & L1 L & L2 & L1 & L2 & L1 & L2 & L1 & L2 & L1 & L2 & L1 & L2 \\
\hline \multicolumn{21}{|l|}{ Muridae } \\
\hline \multicolumn{21}{|l|}{ Arvicolinae } \\
\hline \begin{tabular}{|l|} 
Microtus arvalis \\
\end{tabular} & 7 & 10 & 3 & 7.5 & 10 & 4.5 & 18.5 & 10 & 4 & 1 & 2 & 9 & & & & & 27 & & 2 & 1 \\
\hline Clethrionomys glareolus & 1.5 & & 5.5 & 0.5 & & & & & 3 & & 11 & & 2 & 9 & & 1 & & 1 & 3 & \\
\hline Microtus subterraneus & & & & & & & & & 0.5 & & & & & & & & & & 1 & \\
\hline \multicolumn{21}{|l|}{ Murinae } \\
\hline Apodemus agrarius & & & & & & & 2 & 0.5 & & & 3 & & & & & & 7 & 7 & & \\
\hline Apodemus flavicollis & 1.5 & 0.5 & 10.5 & 7 & 4 & & & 3 & 0.5 & & 1 & & 10 & 10 & 1 & 1 & & 2 & 1 & \\
\hline Apodemus sylvaticus & 1.5 & 1 & 2.5 & 8.5 & 3 & 0.5 & 2 & 6 & 4.5 & & 1 & 3 & 1 & 5 & 9 & 4 & & 1 & 8 & \\
\hline Apodemus uralensis & & & 1 & & & 1 & 0.5 & 0.5 & & 2 & 1 & & & & & 1 & 2 & & & 2 \\
\hline Mus spicilegus & & & & & & & & & 0.5 & & & & & & & & & & 1 & \\
\hline Micromys minutus & & & & & & & & & & 2 & & & & & & & & & & 2 \\
\hline Rattus norvegicus & 1 & & & & & & & & & & & & & & & & & & & \\
\hline \multicolumn{21}{|l|}{ Scoricomorpha } \\
\hline Soricidae & & & & & & & & & & & & & & & & & & & & \\
\hline Crocidura leucodon & 0.5 & & & & & & & & & & & & & & & & & & & \\
\hline Crocidura suaveolens & 1 & & & & & 0.5 & & & & 2.5 & & & & & & & & & & 2 \\
\hline Neomys anomalus & & & & & & & & & 0.5 & & & & & & & & & & & \\
\hline Sorex araneus & & & 1.5 & & & 1 & 0.5 & & & 9 & 1 & & & & 1 & 2 & & 2 & & 7 \\
\hline Sorex minutus & & & 0.5 & & & & & & & 1 & & & & & & & & & & 1 \\
\hline locality score / skóre lokality & 12. & .8 & 24 & 4 & 12.3 & & 21. & .8 & 15.5 & .5 & & 6 & 18 & 3.5 & & 10 & 24. & .5 & & 5.5 \\
\hline $\begin{array}{l}\text { No. of RFF prey species / } \\
\text { počet druhov koristi sokola ko }\end{array}$ & $\begin{array}{r}2 \\
\text { ovit }\end{array}$ & tého & 2 & 2 & 2 & & 2 & $?$ & 2 & & & 2 & 1 & 1 & & 1 & 2 & $?$ & & 2 \\
\hline
\end{tabular}

*genus Mus sp. was identified in diet of red-footed falcon in Slovakia /

*rod Mus sp. bol identifikovaný v potrave sokola kobcovitého na Slovensku

S mall mammals in the food supply of RFF a $t$ the

T v r d o š o v c e s i t e

Altogether 12 small mammal species were recorded here in 2014 (Tab. 2). The most abundant were common shrew (Sorex araneus) (29\%), M. arvalis (16.1\%) and A. sylvaticus (14.5\%). Only at this site we also recorded steppe mouse (Mus spicilegus). M. arvalis, A. sylvaticus and Mus sp. are significant as prey of the redfooted falcon. In 2016 we recorded 11 species of small mammals there. The most abundant species were $A$. sylvaticus (25.8\%) and S. araneus (22.6\%). In 2016 the common vole was absent there.

Site effect on the species c o m p o s i t i o $\mathrm{n}$

In 2014 we recorded nonsignificant site effect on the semiquantitative values of abundance of Orthoptera and
Mantodea among the studied sites $\left(\mathrm{n}=245, \chi_{4}^{2}=8.24\right.$, $\mathrm{P}$ $=0.08$ ). In 2016 the site as a factor has even lower impact on the values of Orthoptera and Mantodea abundance among the studied sites $\left(\mathrm{n}=215, \chi^{2}{ }_{4}=5.52, \mathrm{P}=\right.$ $0.24)$.

In small mammals in 2014 we recorded significant site effect on the semiquantitative values of small mammal abundance among the studied sites $\left(\mathrm{n}=75, \chi^{2}{ }_{4}=\right.$ $13.05, \mathrm{P}<0.01)$. However, we did not record any significant site effect on their abundance in $2016\left(\mathrm{n}=90, \chi^{2}{ }_{4}\right.$ $=14.1, \mathrm{P}=0.84$ ).

Die t preferences of RFF a t the Sysl'ovské polia site duri n g 2014 a n d 2016

Comparison of the diet and food supply showed that the red-footed falcon preferred the great green bush-cricket (T. viridisima) (in 2014: $\mathrm{n}=24 \mathrm{Z}=0.84, \mathrm{CI}: 0.12-$ 


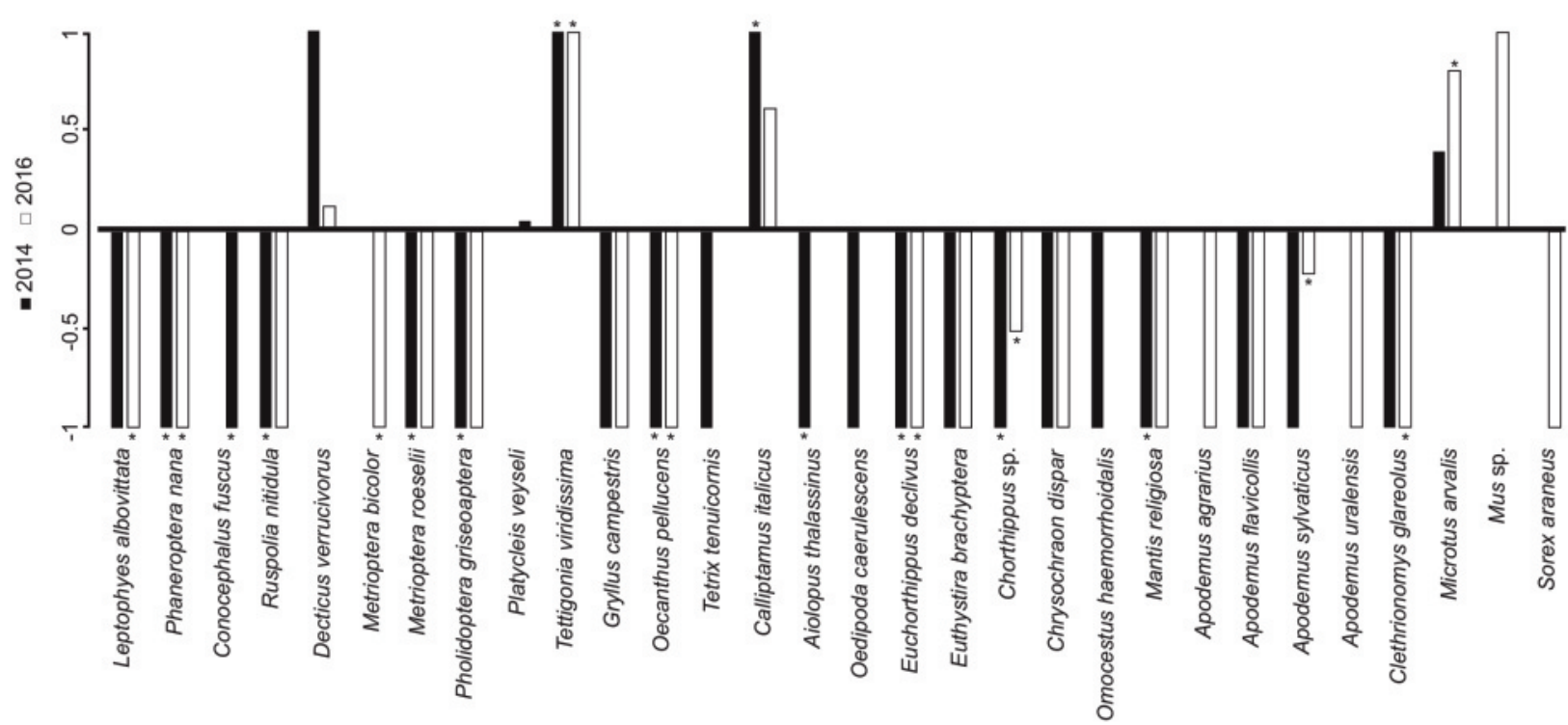

Fig. 4. Ivlev's preference index of the red-footed falcon (RFF) diet at the Sysl'ovské polia site during 2014 and 2016 (-1 - total avoidance of food supply; 1 - total preference of food supply; ${ }^{*}$ - significant preference or avoidance; Chorthippus sp. covers all species of this genus found in the RFF diet).

Obr. 4. Ivlevov index preferencie potravy sokola kobcovitého na lokalite Sysl'ovské polia v priebehu rokov 2014 a 2016 (-1 - celkové vyhýbanie sa potravnému zdroju; 1 - celková preferencia potravného zdroja; * - štatistický významná preferencia resp. vyhýbanie; v rode Chorthippus sp. sú zahrnuté všetky druhy tohto rodu, zaznamenané v potrave sokola kobcovitého).

$0.18, \mathrm{P}<0.05 ;$ in 2016: $\mathrm{n}=25, \mathrm{Z}=0.84$, CI: $0.11-0$. $0.17, \mathrm{P}<0.05)$ as its prey in both studied years. While the proportion of $T$. viridisima in the food supply was $3 \%$ in 2014 and $4 \%$ in 2016 , its proportion in the diet was $20 \%$ in 2014 and $14 \%$ in 2016 . Even though the $C$. italicus was preferred in both years, in comparison with its availability in the breeding territory it was preferred significantly only in $2014(\mathrm{~N}=24, \mathrm{Z}=0.84, \mathrm{CI}$ : $0.05-0.1, \mathrm{P}<0.05$; with $0 \%$ proportion in food supply vs. $11 \%$ in diet). Similar preference was found for the common vole, but it was preferred significant only in $2016(\mathrm{~N}=25, \mathrm{Z}=0.84, \mathrm{CI}: 0.22-0.31, \mathrm{P}<0.05$; with $6 \%$ in food supply vs. $26 \%$ in diet).

Though mice (Mus sp.) were not recorded in the food supply at the Rusovce site during the monitoring of small mammals, in 2016 the species was recorded just once in the diet spectrum of RFF, which was reflected in its high preference. Unexpectedly RFF were seen to avoid preying on the wood mouse, which belonged among the abundant small mammal species at this site in both studied years (with $9 \%$ proportion in food supply vs. $1 \%$ in diet in 2014 and with $12 \%$ in food supply vs. $1 \%$ in diet in 2016). In the preference analysis any species occurring at the site but not forming part of the food, were described as species which the red-footed falcon avoids (Fig. 2).

\section{Discussion}

F o o d s u p p ly

According to the published knowledge from the Pannonian Lowlands, flying insect species represent a major part of the RFF food spectrum, which are supplemented by their hunting of small mammals and other vertebrates (Fülöp \& Szlivka 1988, Haraszthy et al 1994, Purger 1998, Szövenyi 2015, Tulis et al. 2017). From the viewpoint of the food supply and availability of the studied groups of insects and mammals, we consider Tvrdošovce to be the most suitable site for RFF. In both studied years we recorded there not only high abundance but also a great variety of species which had already been recorded in the RFF diet in the past. The next most suitable were the Lehnice, Rusovce and Bodza sites. The Zeleneč site showed itself to be less suitable from the point of view of food availability. In the last seven years, the RFF has been breeding only at Rusovce, most probably because of links with the populations in Hungary and Austria (Palatitz et al. 2015, Dvorak et al. 2016, Slobodník et al. 2017). The 
Tvrdošovce site as well as the other former nesting sites is probably too isolated from the regular breeding population, and that is the reason why despite the quality of their food supply they stay unoccupied by this falcon, also despite their suitable breeding habitats and sufficiency of nest boxes. In terms of the comparison of species composition and abundance it has been found that invertebrates, in comparison to small mammals, showed lower variety both in the interannual comparison of the same sites and between the sites. Certain differences in the availability of invertebrates among the five sites may be explained by the habitat composition effect. Its effect on the species composition in various biotopes has been described for several animal groups, including invertebrates (Fahrig \& Jonsen1998, Söderström et al. 2001). All the observed Slovak former and current nesting sites are situated in agricultural countryside. This is characterized mainly by uniform, large-volume production fields strongly affected by intensification, which has a negative impact on the abundance and species variety of invertebrates (Wickramasinghe et al 2004, Cherrill 2010). In contrast, the species variety of invertebrates increases with growing heterogeneity of the agricultural landscape (Fahrig et al. 2011), in which case the area may supply more potential food sources (Benton 2003). The Rusovce site is composed on the Slovakian side of large-volume production fields (56\%), while the rest of the site on the Austrian side consists of a heterogeneous agricultural landscape which may have a positive impact on the species breeding (Fig. 1). Altogether $63 \%$ of the Lehnice site is included in agro-environmental schemes minimizing the intensification or pesticide covering of the land, and supporting the protection and preservation of natural and semi-natural biotopes. On the other hand, at the Tvrdošovce site only $1.8 \%$ of the area is included in an agro-environmental scheme, and the Bodza and Zeleneč sites are not included in any agro-environmental schemes at all. In any case a significant site effect on the abundance of the potential food was recorded only in the case of small mammals in 2014.

Inter-annual differences in the availability of invertebrates at the particular sites may also be explained by differing natural conditions. Rainfall or low temperatures for example have a negative impact on the amount of insects on various agricultural crops (Beirne 1970, McClure1989).

Regarding small mammals, we did not record fluctuations in their abundance among sites, but in the interannual comparison we recorded the biggest differences in the abundance of the common vole. While in 2014 in south-western Slovakia the species growth culminated and the common vole was the most abundant species of small mammal at all five studied sites, in 2016, with the exception of the Bodza site, there was a sudden slump in its abundance, when at the Lehnice, Zeleneč and Tvrdošovce sites the species was not recorded at all. These results suggest that we probably recorded kind of the population decline typical for fluctuations in the common vole population in the environmental conditions of Central Europe (Jacob \& Tkadlec 2010, Jacob et al. 2013).

It is known (1.c.) that apart from the groups studied by us (small mammals, Orthoptera and Mantodea), the diet spectrum of this falcon species is also composed of beetles (Coleoptera), birds and frogs. However, we have not quantified the availability of these last three animal groups. Especially during humid and cold periods and in wet habitats, the toad Pelobates fuscus for example may become an important part of the red-footed falcon diet (Horváth 1963, Haraszthy et al. 1994). It is then necessary to focus also on the importance of other species of small vertebrates and invertebrates in the food supply of the red-footed falcon at the last breeding sites in Central Europe.

F o o d p r e f e r e n c e s

Dietary opportunism within the characteristic hunting strategies is known in many species of animals and raptors (Jaksić \& Braker 1983, Martin 1987). Based on our results it is evident also in the RFF in Slovakia. The falcon preferred the large insect species (T. viridissima, $D$. verrucivorus, $C$. italicus) and abundant species of small mammals (M. arvalis) in its food supply. Twenty four species from the food supply were marked as "not preferred" (i.e. avoided) species. On the other hand, the availability of several prey groups (frogs, birds, beetles) was not investigated. For example common spadefoots (Pelobates fucscus) can play an important role in the RFF diet during colder and rainy periods of breeding in Hungary (Horváth 1963, Haraszthy et al. 1994). We are therefore not able to adopt a complete standpoint on RFF diet preferences. The species composition of Orthoptera in the food supply and in the diet was studied on the basis of a big sample $(5,164$ specimens from 223 red footed falcon nests) at its nesting sites in southeastern Hungary in a period of three years (Szövényi 2015). This researcher found 26 Orthoptera species in the food supply there, of which 18 species were also found in the diet. Compared with this study, we found 
45 species in the food supply (from cca 14500 identified specimens), though only six Orthoptera species featured in the diet, and overall 10 species in 2007 2016 (Tulis et al. 2017, Fig. 4). This confirms the exceptional variability in the foraging behaviour of the species and the reflection of the food supply in the diet composition. Different results may also reflect different methodological approaches in data collection on the species diet in the studied years. Our food preference analysis shows avoidance of the wood mouse as prey, as this species' activity does not completely overlap with that of the hunting falcon, but it can be trapped also in open habitats, such as mown alfalfa, maize and oil seed rape fields (Zejda 1965, own unpublished results).

It seems to be that the red-footed falcon does not use general hunting strategies in all habitats. The choice of the hunting habitat and its distance from the nest can be influenced by sex and colony size in the red-footed falcon (Palatitz 2011). However, this researcher identified two particular hunting strategies based on the analysis of hunting habitats. The first one involved more hunting over grasslands and alfalfa fields, while the second prioritized grasslands and cereals. We have regularly observed the "air hunting strategy", i.e. the hunting of flying insects in the raptors' territories, mainly above groups of trees and permanent grasslands, and sometimes above stubble fields which are flown over albeit rarely, but mainly by flocks of $C$. italicus .

Conservation i mplications

With regard to conservation and agricultural practice for providing suitable foraging conditions it is necessary to mention that the species survives in an intensive agricultural landscape, the so-called cultural steppe, so its existence is heavily influenced by human activity. Our analysis of food supply and diet in the foraging habitats indicates that red-footed falcons use just the open agricultural landscape with enough permanent grasslands and well-preserved woodland and shrubby dispersed vegetation with minimal use of insecticides and rodenticides. Intensively managed land brings risks connected with the homogeneity of agricultural cultures, where a combination of several negative factors threatens the species diversity. On the other hand, increased heterogeneity in the uniform agricultural landscape may lead to expanding and stabilising of the food sources in all the studied sites. An interesting alternative thus may be ecological compensation areas in the form of wild flower strips and herbaceous borders in which the annual mowing is omitted. Aschwanden et al. (2005) described a mosaic of different habitat types with grassland mown at different times of the year together with undisturbed strips to be most likely to provide a yearround supply of accessible food for vole hunters such as the Eurasian kestrel. Moreover, perennial covers of broadleaved plants may represent enough habitats for insects (mainly Orthoptera and beetles), the most important food for the red-footed falcon. On the other hand, it is important to mention that there are still debates on the clear impact of compensation measures upon biodiversity (Korňan 2014).

Comparison of the red-footed falcon diet from a single Slovak nesting site (Tulis et al. 2017) with the food from other parts of the Pannonian Lowlands (Haraszthy et al. 1994) reveals a low number of frogs in the red-footed falcon diet in Slovakia. Creation of artificial but suitable aquatic habitats, representing natural reservoirs of rainwater, could lead to increased availability of frogs and aquatic insects (e.g. Odonata) in the breeding territories, and they might represent alternative food for the red-footed falcon, bearing in mind both the decline of the common vole and the lack of terrestrial insects in cold and wet years.

\section{References}

Aschwanden J, Birrer S \& Jenni L 2005: Are ecological compensation areas attractive hunting sites for common kestrels (Falco tinnunculus) and long-eared owls (Asio otus)? Journal of Ornithology 146(3): 279-286.

Andersson M \& Erlinge S 1977: Influence of predation on rodent populations. Oikos 29: 591-597.

Beirne BP 1970: Effects of precipitation on crop insects. The Canadian Entomologist 102(11): 1360-1373.

Benton TG, Vickery JA \& Wilson JD 2003: Farmland biodiversity: is habitat heterogeneity the key? Trends in Ecology \& Evolution 18(4): 182-188. DOI: 10.1016/S0169-5347(03)00011-9.

Cramp S \& Simmons KEL 1980: The birds of the western Palearctic, vol. 2. Oxford University Press, 728.

Danko Š 2008: Poštolka rudonohá Falco vespertinus, 288-289 In: Cepák J, Klvaňa P, Škopek J, Schröpfer L, Jelínek M, Hořák D, Formánek J \& Zárybnický J (eds) 2008: Atlas migrace ptáků České republiky a Slovenska [Czech and Slovak bird migration atlas]. Aventinum, Praha, 607. [In Czech with English summary] 
Dvorak MH, Berg M \& Wendelin B 2016: Ornithologische Beiträge zum Managementplan für das SPA „Parndorfer Platte-Heideboden“ Auswertung ornithologischer Erhebungen aus den Jahren 2004-2015. Unpublished report for the Amt der Burgenländischen Landesregierung, Abteilung 5 - Anlagenrecht, Natur- und Umweltschutz. BirdLife Austria, Wien, 123.

Fahrig L \& Jonsen I 1998: Effect of habitat patch characteristics on abundance and diversity of insects in an agricultural landscape. Ecosystems 1(2): 197-205.

Fahrig L, Baudry J, Brotons L, Burel FG, Crist TO, Fuller RJ, Sirami C, Siriwardena GM \& Martin JL 2011: Functional landscape heterogeneity and animal biodiversity in agricultural landscapes. Ecology Letters 14(2): 101-112. DOI: 10.1111/j.1461-0248.2010.01559.x.

Fülöp Z \& Szlivka L 1988: Contribution to the food biology of the red-footed falcon (Falco vespertinus) Aquila 95: 174-81.

Gúgh J, Trnka A, Karaska D \& Ridzoň J 2015: Zásady ochrany významných druhov vtákov a ich biotopov [Principles of protection of significant bird species and their biotopes]. Státna ochrana prírody SR, Banská Bystrica, 332. [In Slovak]

Haraszthy L, Rékási J \& Bagyura J 1994: Food of the red-footed falcon (Falco vespertinus) in the breeding period. Aquila 101: 93-110.

Harz K 1969: Die Orthopteren Europas - The Orthoptera of Europe. Vol. I. The Hague, Dr. W. Junk B. V., 749.

Harz K 1975: Die Orthopteren Europas - The Orthoptera of Europe. Vol. II. The Hague, Dr. W. Junk B. V., 939.

Hoi H, Krištín A, Valera F \& Hoi C 2004: Clutch enlargement in lesser gray shrikes (Lanius minor) in Slovakia when food is superabundant: A maladaptive response? Auk 121: 557-564. DOI: 10.1642/00048038(2004)121[0557:CEILGS]2.0.CO;2.

Holmes RT, Schultz JC \& Nothnagle P 1979: Bird predation on forest insects: an exclosure experiment. Science 206: 462-463.

Horváth L 1963: A kékvércse (Falco vespertinus L.) és a kis örgébics (Lanius minor Gm.) élettörténetének összehasonlító vizsgálata I. A tavaszi érkezéstöl a fiókák kikeléséig [Comparing life history of redfooted falcons and lesser grey shrikes from spring arrival to hatching]. - Vertebrata Hungarica 5(1-2): 69-121. [in Hungarian with German summary]
Cherrill A 2010: Species richness of Orthoptera along gradients of agricultural intensification and urbanisation. Journal of Orthoptera Research 19(2): 293-301.

Ivlev VS 1961: Experimental ecology of the feeding of fishes. Yale University Press, New Haven, 302.

Jacob J \& Tkadlec E 2010: Rodent outbreaks in Europe: dynamics and damage, 207-223. In: Singleton GR, Belmain S, Brown PR \& Hardy B (eds.), Rodent outbreaks: Ecology and impacts, International Rice Research Institute, Los Banos, Philippines, 289.

Jacob J, Manson P, Barfknecht R \& Fredricks T 2013: Common vole (Microtus arvalis) ecology and management: implications for risk assessment of plant protection products. Pest Management Science 70(6): 869-878. DOI: 10.1002/ps.3695.

Jaksić FM \& Braker HE 1983: Food-niche relationships and guild structure of diurnal birds of prey: competition versus opportunism. Canadian Journal of Zoology 61(10): 2230-2241.

Kočárek P, Holuša J \& Vidlička L 2005: Blattaria, Mantodea, Orthoptera \& Dermaptera of the Czech and Slovak Republics. Kabourek, Zlín, 348.

Kočárek P, Holuša J, Vlk R., Marhoul P \& Zuna-Kratky $T$ 2008: Recent expansions of the bush-crickets Phaneroptera falcata and Phaneroptera nana (Orthoptera: Tettigoniidae) in the Czech Republic. Articulata 23: 67-75.

Korňan M 2014: Porovnanie štruktúry hniezdnych ornitocenóz medzi extenzívne spásanými a zarastajúcimi horskými pasienkami v Národnom parku Muránska planina [Comparison of breeding bird assemblage structure between extensive and successional mountain pastures in the Muránska planina National Park]. Tichodroma 26: 31-44. [In Slovak with English summary]

Korpimäki E 1984: Population dynamics of birds of prey in relation to fluctuations in small mammal populations in western Finland. Annales Zoologici Fennici 21: 287-293.

Korpimäki E \& Norrdahl K 1991: Numerical and functional responses of kestrels, short-eared owls, and long-eared owls to vole densities. Ecology 72(3): 814-826.

Korpimäki E \& Wiehn J 1998: Clutch size of kestrels: seasonal decline and experimental evidence for food limitation under fluctuating food conditions. Oikos 83(2): 259-272.

Martin TE 1987: Food as a limit on breeding birds: a life-history perspective. Annual Review of Ecology 
and Systematics 18: 453-487.

McClure MS 1989: Importance of weather to the distribution and abundance of introdud adelgid and scale insects. Agricultural and Forest Meteorology 47(2-4): 291-302.

Morosinotto C, Villers A, Thomson RL, Varjonen R \& Korpimäki E 2017: Competitors and predators alter settlement patterns and reproductive success of an intraguild prey. Ecological Monographs 87(1): 4-20. DOI: $10.1002 / \mathrm{ecm} .1238$.

Neu CW, Byers C R \& Peek JM 1974: A technique for the analysis of utilization-availabiiity data. Journal of Wildlife Management 38: 541-545.

Ontiveros D \& Pleguezuelos JM 2000: Influence of prey densities in the distribution and breeding success of Bonelli's eagle (Hieraaetus fasciatus): management implications. Biological Conservation 93(1): 19-25.

Palatitz P, Fehérvári P, Solt S, Kotymán L, Neidert D \& Harnos A 2011: Exploratory analyses of foraging habitat selection of the red-footed falcon (Falco vespertinus). Acta Zoologica Academiae Scientiarum Hungaricae 57(3): 255-268.

Palatitz P, Fehérvári P, Solt S \& Horváth E 2015: Breeding population trends and pre-migration roostsite survey of the red-footed falcon in Hungary. Ornis Hungarica 23(1): 77-93.

Purger J 1998: Diet of red-footed falcon Falco vespertinus nestlings from hatching to fledging. Ornis Fennica 75(4): 185-191.

R Core Team 2016: A language and environment for statistical computing. R Foundation for Statistical Computing, Vienna, Austria. Retrieved February 22, 2016 from https://www.R-project.org/.

Richardson J 2017: Selectapref: Analysis of field and laboratory foraging, version 0.1.0. Retrieved August 15, 2017 from https://CRAN.R-project.org/package $=$ selectapref.

Slobodník R, Chavko J, Lengyel J, Maderič B \& Noga M 2014: Prežije na Slovensku sokol červenonohý? [Is red-footed falcon going to survive in Slovakia?], 23. In: Lešo P (ed.): Aplikovaná ornitológia, Zborník abstraktov z 26. stredoslovenskej ornitologickej konferencie [Applied ornithology, Proceeding of the $26^{\text {th }}$ Central Slovak Ornithological Conference with International Participation], TU vo Zvolene, Zvolen, 29. [In Slovak]

Slobodník R, Tulis F, Chavko J, Lengyel J 2017: Monitoring of colonies and provisioning of rooks with nest material as a potential tool for stabilizing colonies and increasing nesting opportunities in the countryside. Project report. Slovak Raptor Journal 11: 43-50. DOI: 0.1515/srj-2017-0004.

Söderström BO, Svensson B, Vessby K \& Glimskär A 2001: Plants, insects and birds in semi-natural pastures in relation to local habitat and landscape factors. Biodiversity and Conservation 10(11): 1839-1863.

Tulis F, Slobodník R, Langraf V, Noga M, Krumpálová Z, Šustek Z \& Krištín A 2017: Diet composition of syntopically breeding falcon species Falco vespertinus and Falco tinnunculus in south-western Slovakia. Slovak Raptor Journal 11: 15-30. DOI: 10.1515/srj-2017-0006.

Village A 1982: The home range and density of kestrels in relation to vole abundance. The Journal of Animal Ecology 51(2): 413-428.

Vlk R, Balvín O, Krištín A, Marhoul P \& Hrúz V 2012: Distribution of the southern oak bush-cricket Meconema meridionale (Orthoptera, Tettigoniidae) in the Czech Republic and Slovakia. Folia Oecologica 39: 155-165.

Wickramasinghe LP, Harris S, Jones G \& Vaughan Jennings N 2004: Abundance and species richness of nocturnal insects on organic and conventional farms: effects of agricultural intensification on bat foraging. Conservation Biology 18(5): 1283-1292. DOI: 10.1111/j.1523-1739.2004.00152.x.

Zejda J 1965: Nároky myšice křovinné (Apodemus sylvaticus) na prostredí $\mathrm{v}$ nížinné oblasti [Claims of wood mouse (Apodemus sylvaticus) in lowland environment]. Zoologické listy 14: 301-316. [In Czech] 